\title{
International Water Law in the La Plata Basin: Regional Application of Principles and Procedural Rules of General International Water Law
}

\author{
By Mariana Suzuki Sell, Rio de Janeiro
}

\section{Introduction}

The La Plata Basin spreads throughout south of Brazil, southeast of Bolivia, Uruguay, Paraguay, and northeast of Argentina. Its area is $3,107,000 \mathrm{~km}^{2}$, approximately $17 \%$ of South America's surface. ${ }^{1}$ The main rivers which form the Basin are the Bermejo, Iguaçu, La Plata, Paraguay, Paraná, Pilcomayo, Tietê, and Uruguay Rivers. These rivers, combined with a developed land transportation network, connect areas of intensive production to the ports and to the regional centers of consumption. The Basin also comprises one of the world's largest aquifers, the Guarani, which has reserves estimated at $40,000 \mathrm{~km}^{3}$ of water. It comprises an area of approximately 1.2 million $\mathrm{km}^{2}$, with a population of 15 million. Even though superficial water is abundant in the region, its population is highly dependent on groundwater. ${ }^{2}$

The Basin's territory comprises the capitals of four of the five countries: Asunción, Brasília, Buenos Aires, and Montevideo. The possibility of navigation in the La Plata Basin has prompted the development of politically and economically important urban centers on its margins. Cities like Buenos Aires and Montevideo were primarily founded to serve as ports and control trade. As trade flourished in the Basin, agricultural and industrial development also thrived. Most of the developed agricultural and industrial regions of each of the five countries are located within the Basin, generating $80 \%$ of their combined gross domestic product. Economic development attracted a large number of migrants and resulted in rapid population growth, especially during the last three decades. Nearly $60 \%$ of the total population of the five countries is located in the Basin. ${ }^{3}$ In order to provide the energy

1 José Roberto Borghetti / José Afonso de Oliveira / Elisabeth Sbardelini, Aspectos Ambientais da Bacia do Prata, in Instituto Acqua, Cadernos Acqua, Série Bacia do Prata n. 1, Simpósio Internacional sobre Aspectos Ambientais da Bacia do Prata, Rio de Janeiro, 1994, p. 13.

São Paulo State Government, Secretary of Environment, Environmental Planning Coordination, Projeto GEF: Gerenciamento Integrado e Sustentável do Aqüífero Guarani, 2000, pp. 1-2.

Newton V. Cordeiro, Environmental management issues in the Plata basin, in Asit K. Biswas et al. (ed.), Management of Latin American river basins: Amazon, Plata, and São Francisco, Tokyo: UNU Press, 1999, pp. 148-152. 
demanded by the economic and demographic growth in the region, several (31) large dams were constructed in the Basin and some others are being planned. The hydropower potential of the Basin is $92,000 \mathrm{MW}$, from which approximately half is being utilized. ${ }^{4}$

The Basin comprises a large variety of ecosystems, from the Pantanal - considered the largest wetland in the world, to the Atlantic Forest, the Chaco, and the Savanna. On the other hand, the region is suffering from severe environmental problems, such as erosion, sedimentation, water and soil contamination, which have been of especial concern in the Upper Paraguay River Basin, the Pilcomayo River Basin, the Bermejo River Basin, the Gran Chaco region, and the Mirim Lagoon Basin. ${ }^{5}$

\section{Development of regional international water law in the La Plata Basin}

\section{The establishment of a regional water legal regime and institutional framework}

The development of a regional legal regime and institutional framework for the utilization of the La Plata Basin waters was initiated in the second half of the 1960s. In 1967 the Foreign Ministers of the five countries met for the first time to plan the joint study of the Basin and its potential utilization. They created the Intergovernmental Coordinating Committee of the Countries of the La Plata Basin (CIC) with the purpose of accomplishing such study. The objects of study by the committee are: navigation, hydroelectricity, domestic, sanitary and industrial uses, irrigation, floods and erosion control, animal and vegetal conservation. ${ }^{6}$ In the following year the Statute of the CIC was approved, and the Committee was entrusted to draw up a treaty to establish an institutional framework for the cooperative management of the Basin. The La Plata Basin Treaty was signed by the ministers in 1969. The Parties agreed to unite efforts with the objective of promoting the harmonious development and the physical integration of the La Plata Basin and of its area with direct and considered influence.

Organization of American States, Desarrollo del Comercio en la Cuenca del Plata, in Marco para la gestión sostenible de los recursos hídricos de la Cuenca del Plata en los referente a los aspectos hidrológicos de la variabilidad y cambio climático, http://www.oas.org/usde/plata/comerciof.htm (accessed on 22 November 2004).

Newton V. Cordeiro, Environmental management issues in the Plata basin, in Asit K. Biswas et al. (ed.), Management of Latin American river basins: Amazon, Plata, and São Francisco, Tokyo: UNU Press, 1999, p. 154.

6

Victor Pochat, Water-resources management of the Plata basin, in A.K. Biswas et al. (ed.), Management of Latin American river basins: Amazon, Plata, and São Francisco, Tokyo: UNU Press, 1999, p. 124. 
The CIC was recognized as the permanent organ of Basin, entrusted to promote and coordinate multilateral actions for its integrated development, as well as to promote technical and financial assistance with the support of international organizations. It has also to execute the decisions of the Foreign Ministers, who are to meet once a year. At these yearly meetings the ministers will draw common policies, evaluate the obtained results, consult each other on development actions of their respective governments, direct the work of the CIC, and take the necessary measures for the implementation of the objectives of the La Plata Basin Treaty. This institutional structure was complemented, on June 1974, by the establishment of the Financial Fund for the Development of the Plata Basin (FONPLATA). The Fund has the purpose of assuring financial means for studies, programs, and works to promote the harmonic development and the physical integration of the La Plata Basin. ${ }^{7}$

Finally in 1971 the Declaration of Asunción about the utilization of international rivers was adopted by the five States of the Basin. ${ }^{8}$ It distinguishes contiguous rivers from successive rivers, establishing different rights and duties for the riparian States of each case.

\section{Bilateral and trilateral agreements flourishing}

From the end of the 1960s through the 1970s bilateral and trilateral agreements for the utilization of the La Plata Basin waters flourished. Before then, some important bilateral and trilateral agreements between the Basin States had already been subscribed, such as: the Convention on the Legal Statute of the Frontier between Brazil and Uruguay (1933); the agreement that established the International Commission for the use of the Pilcomayo River (Argentina, Bolivia and Paraguay, 1941); the Convention about the utilization of the falls of the Uruguay River in the Salto Grande Section (Argentina and Uruguay, 1946); and the covenant that established the Technical Mixed Commission for the study of the utilization of hydroelectric energy of the Apipé falls (Argentina and Paraguay, 1958). However the 70 s were a remarkably active period for the conclusion of agreements - and some disagreements - between the Basin States, which were seeking economic development through international cooperation.

Both Brazil and Argentina were interested in exploiting the hydroelectric potential of the Paraná River. Since the Paraná is a contiguous river which forms the border between each of these countries and Paraguay, bilateral agreements were forged for the planning and

Christian Guy Caubet, As Grandes Manobras de Itaipu: energia, diplomacia e direito na Bacia do Prata, São Paulo: Acadêmica, 1989, pp. 69-70.

8 See Laércio F. Betiol, Itaipu: modelo avaçado de cooperação internacional na Bacia do Prata, Rio de Janeiro: Fundação Getúlio Vargas, 1983, p. 296-7, for the Portuguese translation of the Declaration of Asunción, or Resolution n. 25 (translated from the original Spanish text published by Organization of American States, Ríos y lagos: utilización para fines grícolas e industriales, Washington D.C.: Unión Panamericana, 1971, $4^{\text {th }}$ ed., pp. 187-188). 
execution of such works. However, as the Paraná is also a successive river, of which Brazil is an upstream and, Argentina, a downstream riparian, negotiations for its exploitation should have included all three riparian countries.

In 1966 Brazil and Paraguay had agreed to pursue a joint study of the possibilities of hydropower projects on the Paraná River. ${ }^{9}$ In order to accomplish such study, the two countries created a mixed technical commission. ${ }^{10}$ In 1971-72 Argentina and Paraguay celebrated similar agreements about hydropower development on the frontier. ${ }^{11}$ Argentina feared its plans of building hydropower plants on the Paraná River would be harmed by the plans between Brazil and Paraguay, and demanded previous notification and negotiation, to which Brazil opposed.

On September 1972, Argentina and Brazil signed the New York agreement, whose text was later approved by the General Assembly under the Resolution 2995. ${ }^{12}$ This Resolution embraced the no significant harm principle, recognized the importance of previous notification, cooperation, and negotiation in good-faith. Nevertheless, the duty to notify and give information should not be interpreted as to entitle any State to delay or impede the notified work. The New York agreement seemed to have solved the dispute between Argentina and Brazil about the duty of previous notification. However, as the two nations continued to disagree over the extent the duty to previously inform, Argentina denunciated the New York agreement less than one year after its signature. ${ }^{13}$

Whilst recognizing the duty not to cause significant harm to other States, Brazil defended that the country in whose territory the work is to be executed is responsible for determining

Cataratas Act, or Iguaçu Act, signed on June 22, 1966. The Portuguese version of the Act can be found in Itaipu Binacional, Atos oficiais e legislação complementar, Rio de Janeiro, 1977, pp. 3-5.

Agreement between Brazil and Paraguay for the creation of the Mixed Techninal Commission, signed on February 12, 1967. The Portuguese version of the Agreement can be found in Itaipu Binacional, Atos oficiais e legislação complementar, Rio de Janeiro, 1977, pp. 7-8.

The Covenant for the Study of the Utilization of the Resources of the Paraná River (June 16, 1971) and the Agreement for the Study of the Projects of Installation of Barrages on the Rivers that Form Common Frontier (March 8, 1972) (Laércio F. Betiol, Itaipu: modelo avaçado de cooperação internacional na Bacia do Prata, Rio de Janeiro: Fundação Getúlio Vargas, 1983, p. 26).

See Christian Guy Caubet, As Grandes Manobras de Itaipu: energia, diplomacia e direito na Bacia do Prata, São Paulo: Acadêmica, 1989, pp. 100-1, for the Portuguese version of the United Nations Resolution 2995 (XXVII); or the concerned website of the United Nations General Assembly Resolutions, http://ods-dds-ny.un.org/doc/RESOLUTION/GEN/NR0/270/25/IMG/ NR027025.pdf, for the original English text.

Christian Guy Caubet, As Grandes Manobras de Itaipu: energia, diplomacia e direito na Bacia do Prata, São Paulo: Acadêmica, 1989, p. 106; and Laércio F. Betiol, Itaipu: modelo avaçado de cooperação internacional na Bacia do Prata, Rio de Janeiro: Fundação Getúlio Vargas, 1983, p. 117. 
whether it entails a significant harm to other States or not. That is, the evaluation of the work's potential harm would be unilateral, without consultation with co-riparian States. Previous information and consultation would be necessary only if the country who intends to execute the work judges it to be potentially harmful. Otherwise, previous notification and consultation would imply the right of co-riparian States to delay or to veto the concerned work, violating sovereign rights. Argentina, on the other hand, obviously opposed to a unilateral decision, and claimed its right to be previously informed and consulted. It defended such position in the United Nations General Assembly, obtaining the recognition of the duty to previous inform and consult under the Resolutions 3129 (XXVIII) and 3281 $\left(\mathrm{XXIX)}{ }^{14}\right.$

In 1973 Brazil and Paraguay signed the Itaipu Treaty. This treaty created the Itaipu Binacional, an entity entrusted to construct the barrage and produce hydroelectric energy. In the same year Argentina and Paraguay signed the Yacyretá Treaty, very similar to the Itaipu Treaty. Moreover, these two countries intended also to build Corpus Christi, a barrage to be located between Itaipu and Yacyretá.

After two years of negotiations, the conflict was finally resolved when the interested Parties - Argentina, Brazil, and Paraguay - compromised and signed the 1979 Tripartite Agreement of Technical and Operational Cooperation between Itaipu and Corpus. ${ }^{15}$ The Parties agreed to keep good navigability conditions on the Paraná River, a matter of much importance to Argentina and Paraguay. 16

Besides the Itaipu and Yacyretá Treaties, many other bilateral agreements concerned to the utilization of the La Plata Basin waters were forged during the 1970s. Brazil and Uruguay subscribed the Agreement about the Mixed Commission for the Utilization of Mirim Lagoon (1974); the Agreement about River and Lake Transportation (1975); and the Cooperation Treaty for the Utilization of Natural Resources and the Development of Mirim Lagoon Basin (1977). Argentina and Uruguay subscribed the Declaration about water resources (1971); the technical-administrative regulation for the mixed commission of the Salto Grande barrage (1972); the Treaty of Limits of La Plata River and its maritime front (1973); and the Statute of the Uruguay River and the agreement for the constitution of its administrative commission (1975). Argentina and Bolivia signed the Buenos Aires Act

Christian Guy Caubet, As Grandes Manobras de Itaipu: energia, diplomacia e direito na Bacia do Prata, São Paulo: Acadêmica, 1989, pp. 107-9.

Christian Guy Caubet, As Grandes Manobras de Itaipu: energia, diplomacia e direito na Bacia do Prata, São Paulo: Acadêmica, 1989, pp. 285-293; Leonel Itaussu Almeida Mello, A Geopolítica do Brasil e a Bacia do Prata, Manaus: Universidade do Amazonas, 1997, p. 219.

Christian Guy Caubet, As Grandes Manobras de Itaipu: energia, diplomacia e direito na Bacia do Prata, São Paulo: Acadêmica, 1989, p. 307. 
about hydrologic basins (1971). Brazil and Paraguay signed the Treaty of Friendship and Cooperation (1975). After the 1979 Tripartite Agreement, cooperation between Argentina and Brazil thrived. In 1980 they signed the agreement for the Creation of Mixed Commission for the construction of a bridge over the Iguaçu River (1980); and the Treaty for the Utilization of Shared Water Resources of Frontier Sections of Uruguay River and its tributary Pepiri-guaçu (1982). Two years later the two countries subscribed the Agreement of Scientific and Technological Cooperation (1981). From the same period is the URUPABOL Convention (Uruguay, Paraguay and Bolivia, 1981), whose object was improving navigability of their shared watercourses, as well as harmonizing national legislation about navigation

\section{Revitalization of regional cooperation from the $1990 \mathrm{~s}$}

Economic recession in the 1980s halted development and cooperation projects in the region, which were resumed by the Basin States on the following decade. At the dawn of the 1990s, four of the five countries achieved the constitution of the Southern Common Market - Mercosur - through the Asunción Treaty. As economic integration and free trade demand harmonization of legislation and policy, including the ones related to natural resources and environment, the Mercosur parties created the Environmental Specialized Reunion (Reunion Especializada de Medio Ambiente - REMA) with the purpose of analyzing the environmental legislation of each party, later converted into the Sub-Group n. 6 of the Common Market Group (GMC), whose purposes are to promote environmental protection within a free trade system. The four countries have also recently subscribed the Environmental Framework Agreement of the Mercosur which, having sustainable development and environmental protection as its main objectives, demands cooperation for the establishment of common environmental policies and the harmonization of environmental legislation. ${ }^{17}$ Furthermore, bilateral environmental cooperation agreements related to the Mercosur have been concluded between the State-parties. ${ }^{18}$

Apart from the Mercosur regime, the Basin States concluded the following bilateral and trilateral agreements: the Cooperation Agreement for the Utilization of Natural Resources and the Development of the Quaraí River Basin (Brazil and Uruguay, 1991); the creation of the Administrative Binational Commission of the Lower Basin of the Pilcomayo River

Acuerdo Marco sobre Medio Ambiente del Mercosur (Decision n. 2/01, signed on June $21^{\text {st }}$ 2001), Articles 4, 5 and 6(c).

18

Such as the Agreement about Cooperation in Environmental Matter between Brazil and Uruguay, signed on December $28^{\text {th }} 1992$; and the Agreement about Cooperation in Environmental Matter between Brazil and Argentina, signed on April $9^{\text {th }} 1996$ (both agreements can be found in Portuguese in Nadia de Araujo / Frederico V. Magalhães Marques / Márcio Monteiro Reis, Código do Mercosul: Tratados e Legislação, Rio de Janeiro: Renovar, 1998, pp. 486-497). 
(Argentina and Paraguay, 1993); the creation of the Trinational Commission for the Development of the Pilcomayo River Basin (Argentina, Bolivia, and Paraguay, 1995); the creation of the Binational Commission for the Development of the Upper Basin of the Bermejo River and the Grande de Tarija River (Argentina and Bolivia, 1995); the agreement for the construction of natural gas pipelines connecting Santa Cruz de la Sierra to São Paulo (Brazil and Bolivia, 1996); and the Quaraí River Basin Treaty (Brasil e Uruguai, 1997).

Currently the Basin States - except for Bolivia - are executing a project of cooperation for groundwater management with the support of the Global Environment Facility (2003-07). Its objective is to formulate and implement an institutional, legal and technical framework for the preservation and sustainable management of the Guarani Aquifer. ${ }^{19}$

During the 1980s and 90s the activities of the CIC decreased and became overshadowed by those of the bilateral and trilateral commissions and of the Mercosur institutions. In order to revitalize the CIC activities, its statute was reformed, creating a Commission of ten representatives, including a political representative and a technical specialist from each country. The reform has empowered the CIC, providing an effective institutional structure for the coordinated and sustainable management of the Basin. It convened technical meetings in 2001 and 2002 to seek support for the formulation of a strategy for water resources management within the La Plata Basin. As a result, the five Basin countries agreed to develop a Framework for the Sustainable Water Resources Development in the La Plata Basin (Decision CIC n. 2/02-528) under the auspices of the CIC. ${ }^{20}$ The program, which is funded for the most part by the GEF, defines the CIC as the Project Director and Basin Management Institution, as measures of institutional strengthening. Four pilot-projects are to be implemented: Pilcomayo, Paraguay-Paraná Confluence, Itaipu-Yacyretá, and Quaraí River Basin. $^{21}$

Julio Thadeu Kettelhut, Gestão Conjunta de Rios Fronteiriços e Transfronteiriços na América do Sul: Programa da Bacia do Prata, Projetos Piloto Guarani e Quarai e Projeto Manejo Interado e Sustentável dos Recursos Hídricos Transfronteiriços na Bacia do Rio Amazonas, in: Cap-Net Brasil, Oficina de Capacitação de Capacitadores em Gestão Integrada de Recursos Hídricos: Material de Apoio Metodológico e Bibliográfico, São Paulo, 2005.

20

United Nations Environment Programme, Global Environment Facility, Concept Document for Sustainable Water Resources Management in the La Plata River Basin, in Organization Of American States, Marco para la gestión sostenible de los recursos hídricos de la Cuenca del Plata en los referente a los aspectos hidrológicos de la variabilidad y cambio climático, http://www.oas.org/ usde/plata/pdf/conceptpaperGEF.pdf (accessed on 20 November 2004).

21

Julio Thadeu Kettelhut, Gestão Conjunta de Rios Fronteiriços e Transfronteiriços na América do Sul: Programa da Bacia do Prata, Projetos Piloto Guarani e Quarai e Projeto Manejo Interado e Sustentável dos Recursos Hídricos Transfronteiriços na Bacia do Rio Amazonas. In: Cap-Net Brasil, Oficina de Capacitação de Capacitadores em Gestão Integrada de Recursos Hídricos: Material de Apoio Metodológico e Bibliográfico, São Paulo, 2005. 


\section{Application of principles and procedural rules of general international water law in the La Plata Basin}

General principles and procedural rules concerning the use of transboundary waters have been gradually elaborated and recognized in international law since the $17^{\text {th }}$ century, with emphasis on navigation. From the $20^{\text {th }}$ century, as the demand for non-navigational uses increased, international law instruments were elaborated for its regulation, gradually consolidating principles and procedural rules concerning the relation among riparian States, water resources protection, and citizen rights. From the general principles - basin unity, cooperation, equitable and reasonable utilization, no significant harm, sustainable development, preventive principle, precautionary principle, and public participation - and procedural rules - information exchange, prior notification, consultation and negotiation, prior consent, and settlement of disputes - adopted in general international water law, which have been accepted in the regional water law of the La Plata Basin? Furthermore, which of those principles and rules have been or are applied by the La Plata Basin States and how? These are some of the questions to be examined next.

\section{General principles}

a) Basin unity: refers to the basin geo-hydrological indivisibility, recognizing the importance of considering the basin as a whole, including groundwater, in water management. In the case of transboundary basins, the riparian States are interdependent, and should place water management in an international cooperation process. The basin unity principle is implicit in the La Plata Basin Treaty, through the premise that there must be physical integration and join action among the Parties in order to achieve an optimal and sustainable utilization of the regional resources. The Treaty demands studies for the complete understanding of the Basin. However its text does not include the definition of drainage basin.

In practice, however, the basin unity principle has not been applied nor supported by the Basin States, as in the Itaipu barrage and the Pilcomayo River diversion project (1979), in which the upstream countries disregarded the impacts on the downstream countries. The ongoing project for the development of a Framework for Sustainable Water Resources Management in the La Plata Basin, on the other hand, can be read as a sign of reemergence of the basin unity approach sought by the La Plata Basin Treaty. It seeks integration among the isolated management projects currently being executed in the sub-basins, recognizing 
the existing fragmentation among the diverse institutions concerning these sub-basins and lack of communication between them and the CIC. ${ }^{22}$

b) Cooperation: the fundamental role of international cooperation in transboundary basins management stems from their physical indivisibility, having in consideration that the drainage basin limits usually do not correspond to the political frontiers. Most of the treaties concerning the management and utilization of the La Plata Basin waters recognize the importance of cooperation between the Basin States, either by establishing cooperative mechanisms of management - such as joint commissions, or by expressly stating its necessity. ${ }^{23}$ Whereas the positive results and even the necessity of cooperation are obvious for the utilization of contiguous rivers, they are not so for successive rivers, where upstream States often have an advantageous position.

In general, the La Plata Basin experience gives support to the theory that sharing water bodies leads to approximation, rather than conflict. The dispute between Argentina and Brazil about the Itaipu project provoked a serious diplomatic conflict between the two neighbours, but it should be taken into consideration that this dispute had deeper roots stemming from the competition for economic and political hegemony in the region. Finally, negotiations for the accommodation between the Itaipu and Corpus projects not only resulted in the Tripartite Agreement, but it also drew Argentina and Brazil politically closer, prompting cooperation far beyond water management issues - including nuclear and

United Nations Environment Programme (UNEP), Global Environment Facility (GEF). Concept Document for Sustainable Water Resources Management in the La Plata River Basin. In: Organization of American States, Marco para la gestión sostenible de los recursos hídricos de la Cuenca del Plata en los referente a los aspectos hidrológicos de la variabilidad y cambio climático, http://www.oas.org/usde/plata/pdf/conceptpaperGEF.pdf (accessed on 20 November 2004); Julio Thadeu Kettelhut, Gestão Conjunta de Rios Fronteiriços e Transfronteiriços na América do Sul: Programa da Bacia do Prata, Projetos Piloto Guarani e Quarai e Projeto Manejo Interado e Sustentável dos Recursos Hídricos Transfronteiriços na Bacia do Rio Amazonas. In: Cap-Net Brasil, Oficina de Capacitação de Capacitadores em Gestão Integrada de Recursos Hídricos: Material de Apoio Metodológico e Bibliográfico, São Paulo, 2005.

As in the preamble of the covenant for the creation of the Mixed Commission for the study of the utilization of hydroelectric energy of the Apipé Falls (Argentina and Paraguay, 1958); in Articles 58 and 80 of the Treaty of Limits of La Plata River, which call for the promotion the joint scientific studies and cooperative measures for environmental preservation (Argentina and Uruguay, 1973); in Articles XII to XVIII of the Treaty of Friendship and Cooperation between Brazil and Paraguay, which call for cooperation to improve navigation in the shared rivers of The La Plata Basin, to develop the Upper Paraná River, and to utilized groundwater in the Paraguayan Chaco (1975); and in Point 5, K, of the Tripartite Agreement (Argentina, Brazil, and Paraguay, 1979). Cooperation is also demanded by the 1992 Agreement about Cooperation in Environmental Matter between Brazil and Uruguay; the 1996 Agreement about Cooperation in Environmental Matter between Brazil and Argentina; and the preamble and article 5 of the Environmental Framework Agreement of the Mercosur (2001). 
hydroelectric energy, agriculture, scientific research, aerospace technology, telecommunications, tax, trade, transport, insurance, and tourism. ${ }^{24}$

c) Equitable and reasonable utilization: historically, several theories were elaborated to justify water allocation, among them the equitable utilization theory, currently accepted by the international community as a well-established rule of International Law. It is based on the rights equality among all riparian States, not in the sense of allocating equal quantities or equal benefits to all States, but rather meaning that all of them stand on equal positions to satisfy their water needs.

The La Plata Basin Treaty calls for an equitable and reasonable utilization of watercourses (Article 1, single paragraph, b). However, the principle of equitable and reasonable utilization has not found support from the Basin States. ${ }^{25}$ In the dispute against Argentina, for instance, Brazil has opposed to the demand of previous consultation on the grounds of sovereign rights, according to which the utilization of a natural resource should be decided solely by the country in whose territory the utilization occurs.

The Framework for Sustainable Water Resources Management in the La Plata Basin and the Guarani Aquifer System Project are promoting a complete diagnosis of the Basin, considering its diverse ecosystems and the economic activities developed in the region. It is expected that this diagnosis will facilitate its integrated management and the equitable use of its waters.

d) No significant harm: no State has the right to use or permit the use of its territory in such a manner as to cause a serious injury to the territory of another or the properties of persons therein. The no significant harm principle was recognized by the Basin States in several international law agreements. ${ }^{26}$

Christian Guy Caubet, As Grandes Manobras de Itaipu: energia, diplomacia e direito na Bacia do Prata, São Paulo: Acadêmica, 1989, p. 312.

Except for the 1971 Declaration about Water Resources (Argentina and Uruguay), which seems to have adopted the principle of equitable and reasonable utilization (Laércio F. Bertiol, Itaipu: modelo avaçado de cooperação internacional na Bacia do Prata, Rio de Janeiro: Fundação Getúlio Vargas, 1983, p. 25).

26

Declaration concerning the Industrial and Agricultural Use of International Rivers, or Declaration of Montevideo (OAS, 1933), statements 2 and 5; Draft Convention on the Industrial and Agricultural Use of International Rivers and Lakes (Inter-American Juridical Committee, 1965), Article 5; Declaration of Asunción about the utilization of international rivers (1971), Paragraph 2; Treaty of Limits of La Plata River and its maritime front (Argentina and Uruguay, 1973), Article 43; Itaipu Treaty (Brazil and Paraguay, 1973), which refers to the Declaration of Asunción in its preamble; Tripartite Agreement (Argentina, Brazil, and Paraguay, 1979), Point 5, G; Treaty for the Utilization of Shared Water Resources of Frontier Sections of Uruguay River and its tributary Pepiri-guaçu, Article III, Paragraph 1, and Article VI, B (Argentina and Brazil, 1980); and 
The controversy lies in whether this principle entails the obligation of previous notification and consultation or not. That is, whereas some States claimed that the State who plans the works can decide unilaterally if they might cause a significant harm or not, other States believed that such decision should be made upon consultation with the interested States.

This divergence of opinion was the core of the conflict between Brazil and Argentina about the Itaipu Project. Argentina claimed its right to be notified and consulted because the project threatened its own utilization of the Paraná River. Brazil opposed to that claim on the grounds that the project would not provoke, according to its own judgment, an appreciable harm to Argentina. In the 1979 Tripartite Agreement and in the Treaty for the Utilization of Shared Water Resources of Frontier Sections of Uruguay River and its tributary Pepiri-guaçu the two countries finally agreed that neither the planning State nor the other interested State can unilaterally determine the potentiality of significant harm. ${ }^{27}$

e) Sustainable development: it is a rather recent concept, adopted by the World Commission on Environment and Development as defined in its Brundtland Report (1987). Fifteen years before the Report, however, the 1969 La Plata Basin Treaty had already called for rational utilization of natural resources in order to preserve them for the future generations. On the other hand, sustainable development was not established as a guiding principle in the bilateral, trilateral, nor regional agreements concluded among the Basin States until the 1990s, when it started to be included in the environmental agreements related to the Mercosur. The 1992 Canela Declaration, adopted by the Mercosur parties in a preparatory meeting for the aforementioned summit, has determined the internalization of environmental costs, which should not be transferred to future generations. ${ }^{28}$ The 2001 Environmental Framework Agreement of the Mercosur has its main purposes sustainable development and environmental protection. In fact, the expression sustainable development appears seven times in its text, including the preamble, and it applies to water resources management, as well as to sanitation and drinking water quality policies.

It should also be remembered that some significant projects for the sustainable management of the La Plata Basin waters are currently in planning or execution phases, such as the Guarani Aquifer System Project, the Integrated Watershed Management Project for the Pantanal and Upper Paraguay River Basin, and the Framework for Sustainable Water

Agreement about Cooperation in Environmental Matter between Brazil and Uruguay (1992), preamble and Article 3, Paragraph 1.

27

Laércio F. Betiol, Itaipu: modelo avaçado de cooperação internacional na Bacia do Prata, Rio de Janeiro: Fundação Getúlio Vargas, 1983, p. 133; Christian Guy Caubet, As Grandes Manobras de Itaipu: energia, diplomacia e direito na Bacia do Prata, São Paulo: Acadêmica, 1989, pp. 309 and 317. 
Resources Management in the La Plata Basin. Nonetheless, unsustainable economic development continues to be largely practiced in the region, which is dearth of a clear system of binding international rules and sanctions. Projects with high potential for environmental damage, such as the Paraguay-Paraná Waterway, are still being planned in the name of economic development. The Waterway would prompt trade and, consequently, raise employment in agricultural and industrial sectors, which is not only welcome, but deeply needed in the region. On the other hand, it would change the speed of the water flow, resulting in erosion, flooding, destruction of fauna and flora, and perhaps water pollution considering the indirect effects resulting from population growth and urban development attracted by the Waterway.

The actual outcomes of the Framework for Sustainable Water Resources Management in the La Plata Basin Project will indicate whether the Basin States have a true disposition to change the present unsustainable pattern, or whether environmental preservation is still mere political rhetoric.

f) Public participation: the right of participation of interested citizens in environmental management has been well established in international conventions and declarations, starting from the 1992 UN Declaration of Environment and Development (Principle 10) and Agenda 21. In its 2004 Helsinki Revision (Berlin Rules) the ILA enrolled the right of participation among the principles of international law governing the management of all waters, having in consideration that people who are to be affected by decisions have the human right to participate in those decisions. States shall provide access to relevant information, including environmental impact assessment.

The right of participation has not been explicitly adopted by any of the international law instruments concerning the La Plata Basin, but it can be said to be implicitly admitted by the agreements that refer to the 1992 UN Declaration on Environment and Development, such as the 1992 Agreement about Cooperation in Environmental Matter between Brazil and Uruguay, and the 1996 Agreement about Cooperation in Environmental Matter between Brazil and Argentina. Moreover, the Framework for the Sustainable Water Resources Management in the La Plata Basin ${ }^{29}$ and the Guarani Aquifer System Project ${ }^{30}$

United Nations Environment Programme, Global Enrivonment Facility, Concept Document for Sustainable Water Resources Management in the La Plata River Basin, in Organization of American States, Marco para la gestión sostenible de los recursos hídricos de la Cuenca del Plata en los referente a los aspectos hidrológicos de la variabilidad y cambio climático, http://www.oas.org/ usde/plata/pdf/conceptpaperGEF.pdf, p. 26 (accessed on 20 November 2004).

30

Brasil, Agência Nacional de Águas, The Guarani Aquifer System Project. http://www.ana.gov.br/ guarani/projeto/sintese.htm (Portuguese version, accessed on 26 November 2004); Proyecto para la protección ambiental y desarollo sostenible del sistema acuífero guaraní, Secretaría General, 
have proposed activities to promote participation of the local population, environmental education, and public awareness. The Project for Integrated Watershed Management of the Pantanal and Upper Paraguay River Basin similarly foresees stakeholder involvement in the identification and demonstration of remedial measures, as well as in a dialogue process. Public participation is to be sought for the identification of alternative means of economic production or alternative economic activities, as well as minimize environmental degradation in a manner acceptable to the communities. 31

Unfortunately past practice does not demonstrate commitment to consideration of public opinion. The Basin States have executed numerous development projects that not only had serious environmental impact, but also displaced or otherwise harmed local communities, such as the Itaipu and Yacyretá dams.

\section{Procedural rules}

a) Information exchange: the importance of regular exchange of information was recognized by the Basin States in the 1971 Declaration of Asunción, the 1973 Treaty of Limits of La Plata River, and the 1979 Tripartite Agreement. It is a component of the Framework for Sustainable Water Resources Management in the La Plata Basin Project, which seeks the intra-governmental coordination of management policies and practices.

b) Previous notification: as well as the duties to exchange information, consult, and negotiate in good faith, the obligation to previously notify the potentially affected States aims to prevent conflicts. Argentina and Uruguay have embraced the duty of prior notification in the Covenant about the utilization of the falls of the Uruguay River in the Salto Grande Section, in the 1973 Treaty of Limits of La Plata River, and in the 1971 Declaration about Water Resources, having established a reasonable time for the answer of the notified State. As mentioned before, divergence about the duty of prior notification gave rise to a conflict between Argentina and Brazil, resolved by the 1979 Tripartite Agreement.

c) Consultation and negotiation: should follow notification in case of opposition by the notified State, but must not be interpreted as entitling this State with a veto right. Procedures of consultation and negotiation have been established in several agreements among the Basin States, such as the Covenant about the utilization of the falls of the Uruguay

http://www.sg-guarani.org/proyecto/resumen.htm (Spanish version, accessed on 3 December 2004).

31

Organization of American States, Implementation of Integrated Watershed Management Practices for the Pantanal and Upper Paraguay River Basin, http://www.oas.org/usde/ALTOPARA/Pd.htm (accessed on 3 December 2004). 
River in the Salto Grande Section and the Treaty of Limits of La Plata River. Nevertheless, previous consultation has been refused by some of the Basin States in a number of occasions. Argentina, for example, has refused to consult and negotiate with Paraguay about the diversion of waters from the Pilcomayo River. Brazil and Paraguay have refused to consult and negotiate with Argentina about the use of the Paraná River, on the grounds that recognizing such duties would amount to giving a veto power to the latter State. ${ }^{32}$

d) Peaceful settlement of disputes: when States fail to achieve agreement through consultation and negotiation, they should resort to other peaceful means of dispute settlement, such as mediation, conciliation, and adjudication. Peaceful settlement of disputes is required by Article 33 of the Charter of United Nations, which refers to conflicts that might "endanger the maintenance of international peace and security". Most of the international agreements for the utilization of shared waters establish procedural rules for the peaceful settlement of disputes.

The Itaipu Treaty, the 1979 Tripartite Agreement, and the 1980 Treaty for the Utilization of Shared Water Resources of Frontier Sections of Uruguay River and its tributary Pepiriguaçu have established diplomacy as the only means for the resolution of any controversies about the interpretation or application of the Treaty. The Treaty of Limits of La Plata River, on the other hand, has entrusted the Mixed Administrative Commission to settle any dispute between its parties related to La Plata River, as long as the dispute is submitted to its consideration by one of them. If the Parties do not reach an agreement either through the Commission or through direct negotiation, the dispute can be submitted by any of the parties to the United Nations International Court of Justice.

Furthermore, broader initiatives that transcend the sphere of interstate disputes should be underlined. In the context of the Framework Agreement for the Sustainable Water Resources Development in the La Plata Basin, the identification and management of conflicts concerning water use were considered priorities during the Workshop for Strengthening a Common Vision for the La Plata Basin, as well as in the International Seminar for Consolidating the La Plata Basin Transboundary Diagnosis, both held in 2004. Similarly, the Quaraí Pilot Project highlights, among the main actions to be implemented, the water conflicts mitigation program. ${ }^{33}$ The precedence given to conflict prevention and settlement points to the gravity of water use related disputes in the La Plata Basin.

Christian Guy Caubet, As Grandes Manobras de Itaipu: energia, diplomacia e direito na Bacia do Prata, São Paulo: Acadêmica, 1989, p. 185.

33

K. Gestão Conjunta de Rios Fronteiriços e Transfronteiriços na América do Sul: Programa da Bacia do Prata, Projetos Piloto Guarani e Quarai e Projeto Manejo Interado e Sustentável dos Recursos Hídricos Transfronteiriços na Bacia do Rio Amazonas, in Cap-Net Brasil, Oficina de Capacitação de Capacitadores em Gestão Integrada de Recursos Hídricos: Material de Apoio Metodológico e Bibliográfico, São Paulo, 2005. 


\section{Conclusion}

The La Plata Basin is considered one of the great transboundary drainage basins of the world. But apart from the large area it covers, its importance arises rather from its central position in the economy and politics of the region, and from the diversity of ecosystems that the Basin comprises.

As the economies of the riparian States developed around the Basin, allocation of its waters among these States brought about international friction, as well as cooperation. International water law developed in the region especially from the late 1960s, as the riparian States planned several hydroelectric power projects. A basin unity approach to water management was then attempted through the creation of the CIC - Intergovernmental Coordinating Committee - and the periodical meetings of the Foreign Ministers. Alongside the basin unity, other principles embraced by international water law were included in the legal regime established by the Basin States in that period. The 1969 La Plata Basin Treaty and the 1971 Declaration of Asunción - both ratified by all Basin States - either implicitly or explicitly admitted most of the general principles established in international water law, such as the basin unity, cooperation, equitable and reasonable utilization, no substantial harm, and sustainable development.

The practice of the Basin States during the following decades, however, ignored those principles. Bilateral agreements overwhelmed the basin unity approach and the Basin States pursued water development and utilization projects in disregard to the interests of other riparian States, violating the principles of cooperation, equitable and reasonable utilization, and no substantial harm. Despite the variety of projects planned or carried out in the La Plata Basin, the dearth of communication among their planning or executing institutions, and between them and the CIC, impeded a broader and unified vision of the transboundary issues of the Basin, and led to conflict among those institutions. The coordination of efforts and policies is essential to the effective implementation of a sustainable development plan for the Basin.

Recognizing such deficiencies, in 2001 the Basin States decided to reform the CIC Statute in order to recover its role as a coordinating institution. The basin unit approach seems to be re-emerging with the revitalization of the CIC. Moreover, the creation of the Mercosur by four of the five Basin countries has revitalized regional unification, which has extended from economic integration to political, cultural and environmental cooperation. Both the conclusion of the 2001 Environmental Framework Agreement of the Mercosur and the Project for the creation of a Framework for Sustainable Water Resources Management in 
the La Plata Basin reflect the tendency towards integrated management and sustainable use of the La Plata Basin.

The Framework Project, along with the Guarani Aquifer System Project and the Project for Integrated Watershed Management of the Pantanal and Upper Paraguay River Basin, have also embraced the public participation principle. Public participation is an essential component of water and environmental management, and should be promoted throughout all the decision-making process. The ILA has gone beyond this concept, recognizing the right to participation in water management as a human right in its 2004 Helsinki Revision (Berlin Rules).

The application of general principles of international water law certainly cannot be homogeneous throughout the world, having to be adapted to each region according to its history, cultural background, politics, economic needs, and physical characteristics. Yet, those principles have been consolidated throughout the years based on numerous experiences concerning transboundary water utilization and management in diverse regions of the world. From its past experience, the La Plata Basin region has also recognized the importance of those principles, in spite of the remaining reluctance of its riparian States in practice. The increasing integration among the Basin States in the recent years is expected to be translated into a cooperative water management. Depending on the outcomes of the ongoing basin-wide projects, especially the Framework for Sustainable Water Resources Management in the La Plata Basin, the La Plata could become a water management model for application in other large river basins. 